\title{
Gambaran Klinis dan Karakteristik Genetik Human Enterovirus 71 Penyebab Hand Foot and Mouth Disease di Banjarmasin - Kalimantan Selatan Tahun 2016
}

Edi Hartoyo

Bagian Ilmu Kesehatan Anak Fakultas Kedokteran Universitas Lambung Mangkurat/RSUD. Ulin, Banjarmasin

Latar belakang. Hand foot and mouth desease (HFMD) adalah infeksi virus akut yang biasanya menyerang anak dibawah 10 tahun, sangat menular dan dapat menimbulkan komplikasi fatal.

Tujuan. Untuk mengetahui gejala klinis, komplikasi, dan serotipe penyebab HFMD di Banjarmasin.

Metode. Penelitian deskriptif, sampel diambil di poliklinik RSUD Ulin dan RS. Islam Banjarmasin periode November 2015 sampai dengan Febuari 2016 yang terdiagnosis HFMD oleh dokter spesialis anak, terdapat 23 sampel.

Hasil. Dari 23 pasien secara klinis HFMD terdapat 18 (78\%) positif entero virus, 71, 2 (9\%) positif campak, dan 3 (13\%) negatif. Umur rata rata $\pm 20,77$ bulan, laki laki $12(52 \%)$ dan perempuan 11 (48\%). Gejala klinis demam 17 (74\%), rash/ lesi kulit 23 (100\%), susah makan $14(61 \%)$, batuk $8(35 \%)$, pilek $9(39 \%)$, diare 5(22\%), konjungtivitis 2(9\%), muntah 4(17\%), nyeri menelan $14(61 \%)$, dan kenjang 2(9\%).

Kesimpulan. Penyebab HFMD terbanyak adalah EV71, umur tesering kurang dari 3 tahun, gejala klinis terbanyak lesi kulit, demam dan tidak didapatkan komplikasi serius (intakranial). Sari Pediatri 2020;21(5):271-5

Kata kunci: HFMD, gejala klinis, genotype

\section{Clinical Description and Genetic Characteristics of Human Enterovirus 71 Causes of Hand Foot and Mouth Disease in Banjarmasin - Kalimantan Selatan in 2016}

Edi Hartoyo

Background. Hand foot and mouth disease (HFMD) is an acute viral infection that usually attacks children under 10 years, is highly contagious and can cause fatal complications.

Objective. To find out clinical symptoms, complications, and serotypes that cause HFMD in Banjarmasin.

Method. Descriptive research, samples were taken at the clinic of Ulin Regional Hospital and Hospital. Islam Banjarmasin from November 2015 to February 2016 diagnosed with HFMD by pediatricians, there were 23 samples.

Results. From 23 clinically HFMD sufferers there were 18 (78\%) positive Entero virus 71, 2 (9\%) positive for measles and 3 (13\%) results were negative. Average age \pm 20.77 months, men $12(52 \%)$ and women 11 (48\%). Clinical symptoms of fever 17 (74\%), rash / skin lesions $23(100 \%)$, difficulty eating $14(61 \%)$, cough $8(35 \%)$, colds $9(39 \%)$, diarrhea 5 (22\%), conjunctivitis 2 (9\%), vomiting 4 (17\%), painful swallowing $14(61 \%)$ and $2(9 \%)$.

Conclusion. The most common cause of HFMD is EV71, the age of testing is less than 3 years, the most clinical symptoms are skin lesions, fever and no serious complications (intracranial). Sari Pediatri 2020;21(5):271-5

Keywords: HFMD, clinical symptoms, genotype

Alamat korespondensi: Edi Hartoyo. Bagian Ilmu Kesehatan Anak Fakultas Kedokteran Universitas Lambung Mangkurat/RSUD. Ulin Banjarmasin. Email:edihartoyo@yahoo.com 
$H$ and foot and mouth desease adalah penyakit yang disebabkan oleh enterovirus non polio, seperti coxsackievirus A5, A7, A9, A10, A16, B1, B2, B3, B5, echovirus, coxsakie virus, dan enterovirus lainnya. Penyebab tersering dari penyakit ini adalah virus coxsackievirus A-16 dan enterovirus 71 . Virus ini termasuk di dalam keluarga Pikornaviridae yang mempunyai protein RNA yang kecil. Enterovirus memiliki komposisi 4 protein struktural, yakni VP1, VP2, VP3, dan VP4. Protein VP1 merupakan kapsid protein mayor pada permukaan virion, ketika VP4 tidak tereskpose pada permukaan. Pemeriksaan serotipe pada enterovirus yang menginfeksi manusia menggunakan prinsip tes naturalisasi ikatan antara kutub antiserum spesifik, yang secara partikuler merupakan respon serologis terhadap protein VP $1 .{ }^{13}$ Enterovirus 71 dibagi di dalam tiga grup genetic, yaitu A, B dan C.

Distribusi penyebaran penyakit ini terjadi di seluruh belahan dunia dan sering menimbulkan wabah. Di daerah dengan empat musimHFMD lebih sering terjadi di musim panas dan gugur, sedangkan pada daerah tropis terjadi sepanjang tahun. Berdasarkan data dari CDC pada tahun 1997-1998 dilaporkan wabah terbesar yang terjadi akibat HFMD, yaitu terjadi di kawasan Asia Timur dan Asia Tenggara. Sejak tahun 1997, wabah besar HFMD dengan komplikasi neurologi yang berat dan tingkat keparahan kasus dilaporkan terjadi di Malaysia, Taiwan, Singapura, Jepang, dan berbagai negara Asia Pasifik lainnya. HFMD masih menjadi masalah kesehatan yang penting di Singapura dengan angka kejadian per 100.000 populasi meningkat dari 125 pada tahun 2001 menjadi 435 pada tahun 2007. Pada tahun 2011 dilaporkan terjadi wabah HFMD Spanyol yaitu sebanyak 4540 anak usia kurang dari 14 tahun terkena infeksi. ${ }^{6,8}$

Di Indonesia berdasarkan diagnosis secara klinis pernah dilaporkan kejadian luar biasa, yaitu di Batam tujuh kasus (2000), RSCM satu (2000), RS Pondok Indah lima (2000), RS Siloam tiga (2000), Bojonegoro 14 (2001), dan Surakarta 57 kasus (2001). Pada tahun 2016 di Banjarmasin dilaporkan terdapat 18 kasus positif dengan serotipe EV 71.

Infeksi HFMD yang disebabkan oleh EV 71 dimulai dengan adanya demam, sakit tenggorokan lalu timbul lesi di mukosa oral dan lesi kutaneus berupa macula dan vesikel, serta kadang kadang disertai gejala neurologi berat, seperti ensefalitis, poliomielitis seperti paralisis, pankreatitis dan kelainan kardiopulmonal. Penyakit ini merupakan salah satu infeksi virus yang beberapa kasus dapat sembuh sendiri dalam waktu tujuh sampai sepuluh hari dengan masa inkubasi berkisar selama 3-7 hari.

Penelitian ini bertujuan untuk mengetahui gejala klinis serotipe virus penyebab HFMD yang bersirkulasi di Banjarmasin, Kalimantan selatan.

\section{Metode}

Sampel diambil dari pasien terdiagnosis HFMD di poliklinik RS Ulin dan RS Islam Banjarmasin periode bulan November 2015 sampai dengan Febuari 2016, terdapat 23 pasien dan 18 berhasil diambil sampelnya dari swab tenggorok.

Data karateristik dasar dan gejala klinis tertera pada Tabel 1 dan 2. Sementara berdasarkan distribusi lesi tertera pada Tabel 3.

Tabel.1. Karateristik sampel

\begin{tabular}{lll}
\hline Variabel & Jumlah & $\%$ \\
\hline Umur (tahun) & & \\
$<1$ & 4 & 17 \\
$1-<3$ & 9 & 40 \\
$3-<5$ & 6 & 26 \\
$5-10$ & 3 & 13 \\
$>10$ & 1 & 4 \\
Gizi & & \\
Obesitas & 2 & 9 \\
Baik & 15 & 65 \\
Kurang & 6 & 26 \\
Buruk & - & - \\
Jenis kelamin & & \\
Laki laki & 12 & 52 \\
Perempuan & 11 & 48 \\
ASI (bulan) & & \\
$<6$ & 16 & 70 \\
$>6$ & 7 & 30 \\
Riwayat imunisasi & & 78 \\
Lengkap & 13 & 22 \\
Tidak lengkap & 5 & \\
\hline
\end{tabular}


Tabel 2. Gejala klinis

\begin{tabular}{lcc}
\hline Gejala klinis & $\mathrm{N}$ & $\%$ \\
\hline Demam & 13 & 72 \\
Lesi kulit/mukosa & 18 & 100 \\
Sulit makan & 15 & 83 \\
Batuk & 8 & 45 \\
Pilek & 9 & 50 \\
Diare & 5 & 28 \\
Konjungtivitis & 2 & 11 \\
Muntah & 4 & 22 \\
Nyeri menelan & 14 & 78 \\
Kejang & 2 & 11 \\
\hline
\end{tabular}

Tabel 3. Lokasi lesi

\begin{tabular}{lcc}
\hline Lokasi lesi & Jumlah & $\%$ \\
\hline Mulut, telapak tangan dan kaki & 21 & 91 \\
Mulut, telapak kaki & 18 & 78 \\
Mulut,telapak tangan & 20 & 87 \\
Telapak tangan dan Kaki & 12 & 52 \\
Kaki/tangan dan bokong & 13 & 57 \\
Mulut dan bokong & 15 & 65 \\
Seluruh badan & 9 & 39 \\
\hline
\end{tabular}

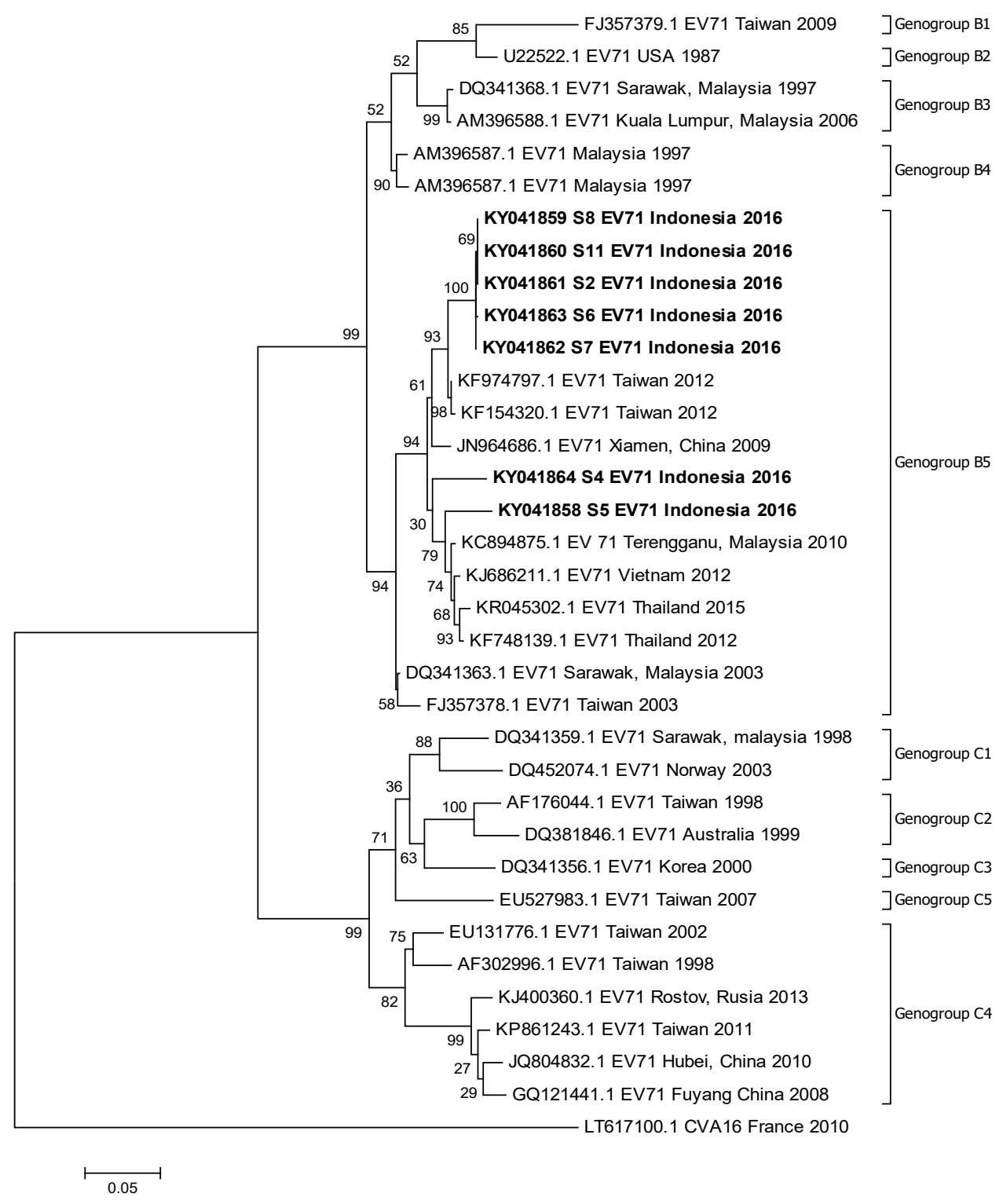

Gambar 1. Analisis konstruksi isolat pohon filogenetik EV71 dari Banjarmasin ${ }^{21}$ 


\section{Pembahasan}

Penyakit menular HFMD menyerang pada anak terutama di bawah usia lima tahun. Penyebab terbanyak adalah virus entero virus 71 dan coxsackie virus 16, dengan gejala demam, nafsu makan menurun, nyeri menelan, malaise dan adanya lesi pada mulut/ tenggorok, telapak tangan, kaki atau bokong, dan bisa mengenai seluruh tubuh. ${ }^{15}$ Pada penelitian kami, umur terbanyak adalah kurang dari tiga tahun, sesuai dengan penelitian sebelumnya. ${ }^{14}$ Jenis kelamin laki laki lebih banyak dibandingkan perempuan (12 berbanding 11 subyek), ini sama dengan penelitian Zou $\mathrm{dkk}^{18}$ dan Panupong $\mathrm{dkk}^{18}$ di Thailand dan Cina. ${ }^{17,18}$ Manifestasi klinis biasanya ringan dan sembuh sendiri, tetapi pada beberapa kasus dapat menyebabkan keadaan berat, seperti pneumonia, meningitis/ensefalitis. ${ }^{16}$ Pada penelitian kami, gejala terbanyak adalah demam $78 \%$, susah makan $83 \%$, hal ini hapir sama dengan penelitian di Cina. ${ }^{17}$ Musim paling sering terjadinya penyakit HFMD adalah musim kemarau (Maret - Juli), berbeda dengan penelitian di Thailand, kasus tebanyak pada musim hujan yaitu bulan Juni - Oktober. Penelitian di Cina penyebaran penyakit HFMD dipengaruhi oleh tingkat kelembaban, kandungan air, dan suhu udara. ${ }^{18}$

Pada penelitian kami penyebab terbanyak adalah EV71, sedangkan penelitian di negara Asia Pasifik penyebab tersering adalah coxsakie 16, 6, dan EV71, tetapi ini sama dengan penelitan di Thiland dan Cina. Di Sarawak, Malaysia, wabah HFMD terutama disebabkan oleh infeksi EV71, dari April Agustus 1997, total 2688 kasus dan 889 anak dirawat di rumah sakit, termasuk 39 pasien dengan meningitis aseptik atau lumpuh layuh akut. Sebanyak 29 anak berusia di bawah enam tahun (median 1,5 tahun), rasio pria-wanita 1,9:1. Pada kasus yang fatal dapat penyebab tersering dari hasil isolasi EV71. ${ }^{17}$ Sementara di Singapura, epidemi HFMD yang disebabkan oleh infeksi EV71 (73\%) terjadi antara September Oktober 2000 dengan 3790 kasus dan tiga kematian. ${ }^{18}$ Usia terbanyak antara 0-4 tahun 1640 kasus, sedangkan periode terbanyak pada bulan Maret-April. Selama epidemi di Singapura, 1,8\% kasus dirawat di rumah sakit. ${ }^{19}$ Pada penelitian kami, sebagian besar pasien ringan, tidak ditemukan komplikasi berat, terdapat dua (11\%) anak dengan kejang demam sedehana, sedangkan usia terbanyak kurang dari 3 tahun.

Infeksi dengan serotipe EV, khususnya anggota spesies enterovirus A, dapat menyebabkan HFMD.
Pada penelitian kami, dominasi EV 71 mungkin sesuai dengan penelitian lain sebelumnya di daerah lain di Asia. Pada penelitian kami, anak yang mendapatkan ASI lebih enam bulan berisiko lebih kecil dibandingkan dengan kurang dari enam bulan. ${ }^{20}$ Lokasi lesi terbanyak adalah pada tangan, kaki, dan mulut sebesar $91 \%$, sedangkan hanya sekitar 36\% lesi menyebar keseluruh tubuh. Penyebaran lesi di seluruh tubuh terjadi pada dua anak dengan obesitas, sedangkan tiga anak gizi buruk dan satu gizi baik. Penelitian di Cina menunjukkan bahwa gejala klinis menjadi berat apabila penderita HFMD berstatus gizi buruk. ${ }^{22}$ Berdasarkan hasil analisis genetik, penelitian kami termasuk di dalam subgrup B5 bersama grup C4 yang merupakan penyebab tersering HFMD di wilayah Asia Pasifik. Subgrup C4 sekarang merupakan subgrup penyebab komplikasi berat pada susunan saraf. ${ }^{21}$ Pada penelitian kami, komplikasi pada susunan saraf tidak terjadi, hampir semua kasus ringan, tidak terdapat pasien rawat inap. Penelitian karakteristik genetik ini merupakan pertama kali dilakukan di Kalimantan.

\section{Kesimpulan}

Penyakit HMFD adalah penyakit virus akut dengan penyebab terbanyak adalah enterovirus 71 dan Coxachie 16. Untuk di Kalimantan Selatan, khususnya Kota Banjarmasin, penyebab terbanyak EV71 dengan gejala terbanyak adalah demam dan adanya lesi di mulut, tangan, dan kaki. Konstruksi isolat pohon filogenik berdekatan dengan virus Malaysia dan Taiwan.

\section{Daftar pustaka}

1. Solomon T, Lewthwaite P, Perera D, Cardosa MJ, McMinn P, Ooi MH. Virology, epidemiology, pathogenesis, and control of enterovirus 71. Lancet Infect Dis 2010 ;10:778-90.

2. Ooi MH, Wong SC, Lewthwaite P, Cardosa MJ, Solomon T. Clinical features, diagnosis, and management of enterovirus 71. Lancet Neurol 2010;9:1097-105.

3. Zhang YF, Deng HL, Fu J, Zhang Y, Wei JQ. Pancreatitis in hand-foot-and-mouth disease caused by enterovirus 71 . World J Gastroenterol 2016;22:2149-52.

4. Wu JM, Wang JN, Tsai YC, Liu CC, Huang CC, Chen YJ, dkk. Cardiopulmonary manifestations of fulminant enterovirus 71 infection. Pediatrics 2002;109:e26. 
5. Yip CCY, Lau SKP, Woo PCY, Yuen K-Y. Human enterovirus 71 epidemics: what's next? Emerg Health Threats J [Internet]. 2013 Sep 10 [cited 2016 Oct 27];6. Available from: http:// www.ncbi.nlm.nih.gov/pmc/articles/PMC3772321/.

6. Fujimoto T, Chikahira M, Yoshida S, Ebira H, Hasegawa A, Totsuka A, dkk. Outbreak of central nervous system disease associated with hand, foot, and mouth disease in Japan during the summer of 2000: Detection and molecular epidemiology of enterovirus 71. Microbiol Immunol 2002 1;46:621-7.

7. Chan LG, Parashar UD, Lye MS, Ong FG, Zaki SR, Alexander JP, dkk. Deaths of children during an outbreak of hand, foot, and mouth disease in sarawak, Malaysia: clinical and pathological characteristics of the disease. For the outbreak study group. Clin Infect Dis $2000 ; 31: 678-83$.

8. Ho M, Chen ER, Hsu KH, Twu SJ, Chen KT, Tsai SF, dkk. An epidemic of enterovirus 71 infection in Taiwan. Taiwan Enterovirus Epidemic Working Group. N Engl J Med 1999 ;341:929-35.

9. McMinn P, Lindsay K, Perera D, Chan HM, Chan KP, Cardosa MJ. Phylogenetic analysis of enterovirus 71 strains isolated during linked epidemics in Malaysia, Singapore, and Western Australia. J Virol 2001;75:7732-8.

10. Wang J-R, Tuan Y-C, Tsai H-P, Yan J-J, Liu C-C, Su I-J. Change of major genotype of enterovirus 71 in outbreaks of hand-foot-and-mouth disease in Taiwan between 1998 and 2000. J Clin Microbiol 2002;40:10-5.

11. Mauleekoonphairoj J, Puenpa J, Korkong S, Vongpunsawad S, Poovorawan Y. Prevalence of Human Enterovirus among patient with Hand Foot and mouth desease and Herpangina in Thailand, 2013. Southeast Asian J Trop Med Public Health $2015 ; 46: 1013-20$.

12. Wu Y, Yeo A, Phoon MC, Tan EL, Poh CL, Quak SH, dkkdkk. The largest outbreak of hand; foot and mouth disease in Singapore in 2008: the role of enterovirus 71 and coxsackievirus A strains. Int J Infect Dis 2010;14:e107681.

13. Shih SR, Ho MS, Lin KH, Wu SL, Chen YT, Wu CN, dkk.
Genetic analysis of enterovirus 71 isolated from fatal and nonfatal cases of hand, foot and mouth disease during an epidemic in Taiwan, 1998. Virus Res 2000;68:127-36.

14. Rao DC, Naidu JR, Maiya PP, Babu A, Bailly JL. Largescale HFMD epidemics caused by Coxsackievirus A16 in Bangalore, India during 2013 and 2015. Infect Genet Evol 2017;55:228-35.

15. Centers for Disease Control and Prevention (CDC). Outbreak case definitions. 2019. Diakses pada 20Februari 2020. Didapat dari: https://www.cdc.gov/urdo/downloads/casedefinitions.pdf.

16. Suzzana B, Barbara D. Hand, foot and mouth desease an as emerging public health problem cases report familial of child to adult transmission. Dent Med Probl 2018;55:94-104.

17. Panupong U, Tawatchai A, Wipob S, Niwed K, Ratipark T, Chadaporn. Molecular epidemiology and clinical feature of hand,foot and mouth disease in northern Thailand in 2016: a prospective cohort. Thailand.J Hainan Med Univ 2014;20:552-5.

18. Zou XN, Zhang XZ, Wang B, Qiu YT. Etiologic and epidemiologic analysis of hand, foot, and mouth disease in Guangzhou city: a review of 4,753 cases the. Braz J Infect Dis 2012;16:457-65.

19. Xu J, Zhao D, Su H, Xie M, Cheng J, Wang X, dkk. Impact of temperature variability on childhood hand, foot and mouth disease in Huainan. China Public Health 2016;134:86-94.

20. Chan JH, Law CK, Hamblion E, Fung H, Rudge J. Best practices to prevent transmission and control outbreaks of hand foot and mouth desease in childcare facilities: a systematic review. Hong Kong Med J 2017;23:177-90.

21. Ageng W, Edi H, Angke J, dkk. Detection and genetic characterization of human enterovirus A71 from hand foot and mouth disease case in Banjarmasin, Indonesia. Southeast Asian J Trop Med Public Health 2018;49:820-5.

22. Yong, Yin Yen. Nutritional status of children with severe hand-foot-mouth disease and its correlation with target organ damage and immune response. J Hainan Med Univ 2016;22:103-6. 